\title{
Trophic structure of a neotropical frugivore community: is there competition between birds and bats?
}

\author{
J.M. Palmeirim ${ }^{1, *}$, D.L. Gorchov ${ }^{2, * *}$, and S. Stoleson ${ }^{3}$ \\ ${ }^{1}$ Museum of Natural History and Department of Systematics and Ecology, Lawrence, KS 66045, USA \\ ${ }^{2}$ Department of Biology, University of Michigan, Ann Arbor, MI 48109-1048, USA \\ ${ }^{3} 10$ Lounsbury Rd., Trumbull, CT 06611, USA
}

\begin{abstract}
Summary. Dietary overlap and competition between frugivorous birds and bats in the Neotropics have been presumed to be low, but comparative data have been lacking. We determined the diets of volant frugivores in an early successional patch of Costa Rican wet forest over a one month period. Ordination of the diet matrix by Reciprocal Averaging revealed that birds and bats tend to feed on different sets of fruits and that diets differed more among bat species than among bird species. However, there was overlap between Scarlet-rumped Tanagers and three Carollia bat species on fruits of several Piper species which comprised most of the diet of these bats. Day/night exclosure experiments on $P$. friedrichsthalli treetlets provided evidence that birds deplete the amount of ripe fruit available to bats. These results indicate that distantly related taxa may overlap in diet and compete for fruit, despite the apparent adaptation of animal-dispersed plant species for dispersal by particular animal taxa.
\end{abstract}

Key words: Competition - Frugivory - Piper - Community Structure - Seed dispersal

It is generally accepted that fruits of some plant species are adapted for dispersal by certain animal taxa. The "syndromes" characteristic of fruits adapted for bird-dispersal and those adapted for bat-dispersal have been described elsewhere (e.g., Pij1 1957; Snow 1971; Pijl 1982; Janson 1983; Knight and Siegfried 1983; Gautier-Hion et al. 1985; Howe 1986). However, little is known of the extent to which these two taxa use the same fruits. A few studies of animaldispersed plant species report frugivory by both birds and bats (August 1981; Estrada et al. 1984a; Fleming et al. 1985; Charles-Dominique and Cooper 1986) but provide no data on the importance of this dietary overlap to the species involved.

Little is known of the importance of dietary overlap between distantly related terrestrial animal taxa on competition and community structure, although increased attention

\footnotetext{
* Present address and address for offprint requests: Departamento de Zoologia, Faculdade de Ciências, Universidade de Lisboa, 1700 Lisboa, Portugal

** Present address: Department of Biology, Princeton University, Princeton, NJ 08544, USA
}

has been focused on this question in the past decade (e.g. Brown et al. 1979). Fleming (1979) concluded that neotropical birds and bats overlap little in their use of fruit and that these two groups do not compete with each other for food. However, his conclusions were primarily based on studies of food habits done in different areas. To determine if there is potential competition between frugivorous bird and bat species we need quantitative data on the dietary overlap between taxa in the same macrohabitat, supplemented with field experiments on resource use. We present data on a comparison of fruit use by birds and bats at a single site during one month and the results of an exclusion experiment designed to test for competition for a shared fruit resource. We also provide a description of the trophic structure of the bird-bat frugivore community and attempt to identify the fruit species that are most important in determining this structure during the time window studied. Only a few studies have been done on the trophic organization of communities of tropical frugivorous birds (Snow and Snow 1971; Crome 1975; Frith et al. 1976; Crome 1978; Wheelwright et al. 1984) and to our knowledge only two papers (Heithaus et al. 1975; Bonacoorso 1979) refer to this subject for frugivorous bats.

\section{Methods}

Study site

This research was done at the early successional strips of the Organization for Tropical Studies' La Selva Biological Station $\left(10^{\circ} 26^{\prime} \mathrm{N}, 83^{\circ} 59^{\prime} \mathrm{W}\right)$ Heredia Province, Costa Rica. This part of La Selva is considered Tropical Premontane Wet Forest (Holdridge et al. 1971). Rainfall is about $4000 \mathrm{~mm}$ per year, with January through April usually drier than the other months (Hartshorn 1983).

The successional strips consist of five 0.5 ha adjacent plots cut on a five-year rotation. This study was done shortly before the annual clearing, so the plots were of ages one through five years. Vegetation on the younger plots was very dense and shrubby, older plots included many trees 2-4 m tall. Hartshorn (1983) described the strips as dominated by the forbs Erechtites hieracifolia and Phytolacca rivinoides in the first year, followed by rapid growth of the treelets Acalypha spp., Colubrina spinosa, Hamelia patens, Miconia affinis, Neea laetevirens, Piper spp., and 
Solanum rugosum, and the pioneer trees Cecropia obtusifolia, Heliocarpus appendiculatus, and Ochroma lagopus. During the course of our study large numbers of fruits of Piper sancti-felicis, Hamelia patens, and Phytolacca rivinoides ripened in the strips, and in general, fruit was much more abundant than in the understory of nearby primary and secondary rainforest.

\section{Determination of bird and bat diets}

We caught birds and bats using $19 \mathrm{~mm}$ mesh mist-nets set up along and across paths in the successional strips. Netting was done early in the dry season (4 Jan.-4 Feb. 1985), which along with the end of the wet season, is often a time of low fruit abundance (Levey 1986). We limited our sampling to a one month period to minimize variation in diets induced by seasonal changes in fruit availability. All birds were netted during the morning, and bats during the evening hours. Nets were checked at approx. 30 minutes intervals and moved every 2-4 days. Daytime netting effort was 400 net-hours ( $14 \mathrm{~m}$ nets), night net effort was 220 nethours (140 of $14 \mathrm{~m}$ nets, 80 of $6 \mathrm{~m}$ nets). Nets extended from near the ground to $3 \mathrm{~m}$.

Each captured animal (except for hummingbirds and vampire bats) was held in a cloth bag for $30 \mathrm{~min}$ and then released. Bags were immediately checked for fecal samples or regurgitated seeds (hereafter grouped as "diet samples"), which were transferred to waxed paper envelopes, and labelled for later analysis. Seeds in diet samples were identified by comparison to a reference collection we made from fruits collected both in the successional strips and in the forest and a reference collection developed by Doug Levey. If the first ten individual diet samples from an animal species yielded no intact seeds, we released subsequent individuals of that species upon capture. Each diet sample that contained one or more intact seeds of a plant species was considered one "record" of that animal eating that fruit, regardless of the number of seeds present in the diet sample.

These sampling methods are biased against animals that avoid nets or do not fly below $3 \mathrm{~m}$. There is also a bias against detecting plants with large seeds since bats do not ingest these (Bonaccorso et al. 1980) and birds regurgitate large seeds faster than they pass small seeds (Johnson et al. 1985; Levey 1987).

\section{Analysis of diet data}

Reciprocal Averaging (RA) (also called Correspondence Analysis) was used to find the best simultaneous representation of the matrix of diet records (with frugivore species as rows and fruit species as columns). RA is a non-parametric analog to Principal Components Analysis (PCA) that is appropriate for data in the form of a contingency table. Like PCA, RA involves the derivation of new axes that maximally account for the structure of the points in a multidimensional space, making possible the reduction of dimensionality. These new axes maximize the correspondence between row and column categories (frugivore and fruit species) so that species with similar diets are positioned close to each other as are fruits eaten by similar sets of animals species (Gauch 1982; Pielou 1984). RA was done using the CORAN computer program (Lebart et al. 1984).

We included in this analysis only bird and bat species for which we had obtained five or more diet samples that each contained at least one intact seed. We included plant species if their seeds had been recovered in two or more diet samples of animals meeting the above criteria.

In addition to RA of the matrix of counts of diet records, we also applied RA to the matrix of presence vs. absence of each fruit species in the diet of each major frugivore. Results of this analysis were qualitatively similar to those for RA of the count data matrix for the first two axes, so we present only the analysis of the count data.

Niche breadth was measured using the index proposed by Levins (1968):

$B=1 / \operatorname{sum} x_{\mathrm{i}}^{2}$ where $x_{\mathrm{i}}$ is the proportion of the fruit portion of an animal species diet that is comprised of plant species $i$. In the calculation of these proportions, we included all plant species and considered each diet record as a single observation. Niche breadth was also calculated after pooling all plant species in the same genus. A Kruskall-Wallis nonparametric test (Sokal and Rohlf 1969) was used to compare niche breath in birds and bats.

Fruit diet overlap between pairs of species was done using Horn's (1966) modification of Morisita's index of overlap. This index ranges from 0 (no overlap) to 1 (complete overlap) and, because it combines diet choices multiplicatively, it is an appropriate measure of the overlap in resource exploitation between species in the same habitat (Horn 1966). This is calculated as $C=2 \operatorname{sum} x_{\mathrm{i}} y_{\mathrm{i}} /\left(\operatorname{sum} x_{\mathrm{i}}{ }^{2}+\right.$ sum $y_{\mathrm{i}}^{2}$ ) where $x_{\mathrm{i}}=$ the proportion of animal species' $x$ 's diet that is made up of food item $i$ and $y_{i}=$ the proportion of animal species' $y$ 's diet made up of food $i$. The data used were the same as for the calculation of niche breadth (above).

To compare statistically the amount of diet overlap between bird species with that between bat species a simulation was performed. To preserve the natural structure of diets, diets as observed were reassigned to birds and bats equiprobably at random. The mean difference between dietary overlaps within each of the 100 simulated bird and bat groups was calculated. The empirical distribution of these simulated differences was used to estimate the significance of the difference in mean dietary overlap between the birds and bats as observed.

\section{Seed germination experiments}

To investigate the consequences of bird vs. bat frugivory on Piper on seed dispersal, we tested germination of birdand bat-passed seeds. Seeds of Piper friedrichsthalli and $P$. sancti-felicis were taken from ripe fruits and fecal samples of Scarlet-rumped Tanagers, Ramphocelus passerinii, and Carollia bats and wiped dry. After about 30 days they were placed on moist filter paper in covered petri dishes and kept at room temperature and daylight. The number of seeds that germinated within two weeks was recorded.

\section{Bird and bat exclosure experiments with Piper}

During the course of this study it became clear that the greatest overlap in fruit use between birds and bats was on Piper spp. A second early successional site was chosen for manipulations in Piper plants to assess whether there was competition between these taxa for Piper fruits. This site was on the east side of the Rio Puerto Viejo, approx. $1.1 \mathrm{~km}$ northwest of the successional strips. Most of this area was grassy and dotted with treelets of Piper friedrichs- 
thalli (D. Kearns, pers. comm.); it was bordered by secondary forest and pasture. This area is now the site of the new La Selva dormitory and dining facilities.

Preliminary observations in this area confirmed that Scarlet-rumped Tanagers and Carollia perspicillata were eating $P$. friedrichsthalli fruits. Additional mist-netting was done in this site 3 and $4 \mathrm{Feb}$. to document the similarity of the volant frugivore community to that in the successional strips. In these two days of netting we caught 10 of the 14 major frugivore species of the successional strips. Diet samples and direct observations confirmed that $P$. friedrichsthalli was eaten by $C$. perspicillata and Scarletrumped Tanagers at the experimental site.

Three $P$. friedrichsthalli treelets, $3-4 \mathrm{~m}$ high, were assigned to each of the following treatments: 1) covered during the day (hence fruits exposed only to nocturnal frugivores), 2) covered at night (exposed only to diurnal frugivores), or 3) never covered (exposed to both), hereafter referred to as the control. (On one of the treelets, which had two trunks leaning in opposite directions, we assigned one trunk to each of the first two treatments.) One of the treatment 1 treelets was badly damaged during the experiment and was therefore excluded from the analysis. Exclosures were made of Ross Garden Net (polypropylene with mesh size: $18 \mathrm{~mm}$ ) secured to a framework of nylon cord with twist-ties. In some cases exclosures did not cover all the trunks of a treelet, but only fruits in the portions covered were monitored.

Branches (18-60 per treelet) bearing "fruits" (technically infructescences) large enough to ripen during the course of this experiment were tagged just proximal to the first fruit with $2 \mathrm{~cm}$ white Avery dumbbell tags. Fruits on the three most proximal nodes of each branch were given a small black mark at the base with a felt-tip marker. In Piper, a single inflorescence is produced at each node during expansion, so the most proximal fruits on any branch are the oldest, and hence ripen first. Thirty-four to 141 fruits were marked on each plant.

In order to deter mammals from climbing the selected trunks, we wrapped them with a sheet of polypropylene from about $40 \mathrm{~cm}$ to $80 \mathrm{~cm}$ above the ground.

The experiment was run for nine days $(29 \mathrm{Jan}$. to 6 Feb. 1985). Each day at dawn (05:45-06:15) two of us would first cover treatment 1 plants and then uncover treatment 2 plants, while the third person censused fruits on control plants. At dusk (17:30-18:00) we would first cover treatment 2 plants and then uncover treatment 1 , concurrent with the census of control plants.

To recover fallen fruits we suspended a layer of fiberglass window screening ( $2 \mathrm{~mm}$ mesh) beneath each treelet in all three treatments. This screening formed the bottom of each exclosure. Screens were checked at dawn and dusk for fallen fruits which were checked for the presence of the black mark near the base, for ripeness, and for signs of partial frugivory. Ripe fallen fruits that were not partially eaten may have been dropped by frugivores or may have fallen for other reasons, but in either case represent fruits that were ripe and available but not consumed. Unripe fallen fruits were not included in the analysis.

At each dawn and dusk all marked fruits on control plants were checked for presence/absence and damage. Marked fruits on treatment and 2 plants were similarly checked, but only every few days and again at the end of the experiment.
To determine whether birds or bats removed fruits at different stages or ripeness, we made daily diameter measurements of a set of individually marked fruits on two plants that were censused each dawn and dusk. Fruits were measured near the base to the nearest $0.1 \mathrm{~mm}$ with Vernier calipers. (Piper fruits do not change color as they ripen, but rather swell, soften, and produce an odor, so diameter was considered the most objective index of maturity.)

\section{Results}

We obtained diet samples from 333 birds ( 53 species) and 211 bats (19 species) netted in the successional strips. We found intact seeds in at least one diet sample from 22 of the bird species and 10 of the bat species. Birds took a greater number of fruit types than bats; of the 59 plant species with seeds distinguishable in the diet samples, 34 species were obtained only from birds, 19 only from bats, and 6 from both birds and bats. Some of the fruits were probably taken outside the successional strips, but at least 13 of the 17 species most commonly found in diet records were present and fruiting within or at the edge of the strips.

Seven bird species and seven bat species (henceforth referred to as the "major frugivores" at the site) yielded five or more diet samples with intact seeds. Intact seeds of 35 plant species were found in diet sample from two or more individuals of these 14 major frugivores (henceforth "major fruit species"). The diet matrix of major frugivores and fruits is given in Table 1.

Arthropod parts were found in diet samples of all seven major frugivorous birds and one of the major frugivorous bat species (Table 2). No attempt was made to identify these arthropods, and they are not included in the statistical analyses. Frugivorous bats in Costa Rican dry forest make frequent use of nectar and pollen (Heithaus et al. 1985), but whether these resources were eaten by the frugivorous bats at our wet forest site could not be detected with our methods.

Analysis of the diet matrix (Table 1) by Reciprocal Averaging revealed significant structure among the major frugivores and their food plants. The first axis accounted for $20 \%$ of the variance and separated bats and fruits fed on by bats from birds and bird-fruits (Fig. 1). Three fruit species (no 16-Piper auritum, no 17 - Pothomorphe peltatum, and no 18 - Lycianthes multiflorum) used by both birds and bats occupy intermediate positions on this axis. Of the seven major avian frugivores, the Scarlet-rumped Tanager (SRTA) lies closest to the bat species, reflecting this species' use of fruits primarily eaten by bats.

The bats and bat-fruits also separated out along the second axis, which accounted for $18 \%$ of the variance (Fig. 1). The two large Artibeus species, and their major food, Ficus insipida, had high scores on the second axis, while the three Carollia species and their major foods (Piper spp., Cassia fruticosa, etc.) had low scores. The two remaining bat species (A. phaeotis and Vampyrops helleri) occupied intermediate positions, reflecting their dietary overlap with both of the first two groups.

The third axis accounted for $13 \%$ of the variance and separated the Ochre-bellied Flycatcher and the fruits only eaten by this species from the six other major avian frugivores and the remaining bird-fruits (Fig. 2). The three fruits eaten by this flycatcher but not by the other birds (Casearia corymbosum (no 23), no 20, no 19) are all large-seeded 
Table 1. Matrix of records of seeds in the diets of the 14 major frugivorous bird and bat species. Each entry is the number of captured animals with one or more seeds present in its diet sample (fecal sample or regurgitation). Blanks represent zeroes. Latin names of birds are given in Table 2. Plant species are listed in order of their scores for the first axis of Reciprocal Averaging

\begin{tabular}{|c|c|c|c|c|c|c|c|c|c|c|c|c|c|c|c|}
\hline \multirow[t]{2}{*}{ Frugivore species } & \multirow[t]{2}{*}{ Abbr. } & \multicolumn{14}{|c|}{ Plant Species ${ }^{\mathbf{a}}$} \\
\hline & & 1 & 2 & 3 & 4 & 5 & 6 & 7 & 8 & 9 & 10 & 11 & 12 & 13 & 14 \\
\hline \multicolumn{16}{|l|}{ BATS } \\
\hline Artibeus jamaicensis & AJAM & 5 & & & & & & & & & & & & & \\
\hline Artibeus lituratus & ALIT & 7 & 3 & & & & & & & & & & & & \\
\hline Vampyrops helleri & VHEL & & 4 & & 1 & & & & & & & & & & \\
\hline Artibeus phaeotis & APHA & & 4 & 2 & 1 & & & & & & & & & & \\
\hline Carollia perspicillata & CPER & & & & 1 & 11 & 9 & & 1 & & & & & 5 & 3 \\
\hline Carollia brevicauda & CBRE & 1 & & & 4 & 6 & 3 & 3 & 7 & 2 & 1 & 1 & & 16 & 1 \\
\hline $\begin{array}{l}\text { Carollia castanea } \\
\text { BIRDS }\end{array}$ & CCAS & & 1 & & & 1 & 5 & & 8 & 1 & 1 & 1 & 2 & 15 & 13 \\
\hline Scarlet-rumped Tanager & SRTA & & & & & & & & & & & & & 1 & 1 \\
\hline Ochre-bellied Flycatcher & OBFL & & & & & & & & & & & & & & \\
\hline Buff-throated Saltator & BTSA & & & & & & & & & & & & & & \\
\hline White-collared Manakin & WCMA & & & & & & & & & & & & & & \\
\hline Clay-colored Robin & CCRO & & & & & & & & & & & & & & \\
\hline Gray Catbird & GCAT & & & & & & & & & & & & & & \\
\hline Wood Thrush & WTHR & & & & & & & & & & & & & & \\
\hline
\end{tabular}

a $1=$ Ficus insipida, 2= Cecropia obtusifolia, $3=$ Ficus sp. 2, 4=Solanum rugosum, $5=$ Cassia fruticosa, $6=$ Piper friedrichsthalli, $7=$ unk., $8=$ Piper arieianum, $9=P$. cenocladum, $10=$ unk. Piper sp., $11=$ unk., $12=$ unk. Piper sp., $13=P$. sancti-felicis, $14=P$. multiplinervum, $15=$ Vismia sp., 16=Piper auritum, 17= Pothomorphe peltatum, 18=Lycianthes multiflorum, 19=unk., 20=unk., $21=$ Ficus colubrinae, $22=$ Conostegia subcrus lata, $23=$ Casearia corymbosum, $24=$ Phytolacca rivinoides, $25=$ Clibadium pittieri, $26=$ Hamelia patens, $27=$ Witheringia asterotricha, $28=$ unk., $29=$ Hampea appendiculata, $30=$ Ficus pertusa, $31=$ Miconia barbinervis, $32=$ Neea laetevirens, $33=$ unk., $34=$ Xiphidium caeruleum, $35=$ Psychotria pittieri

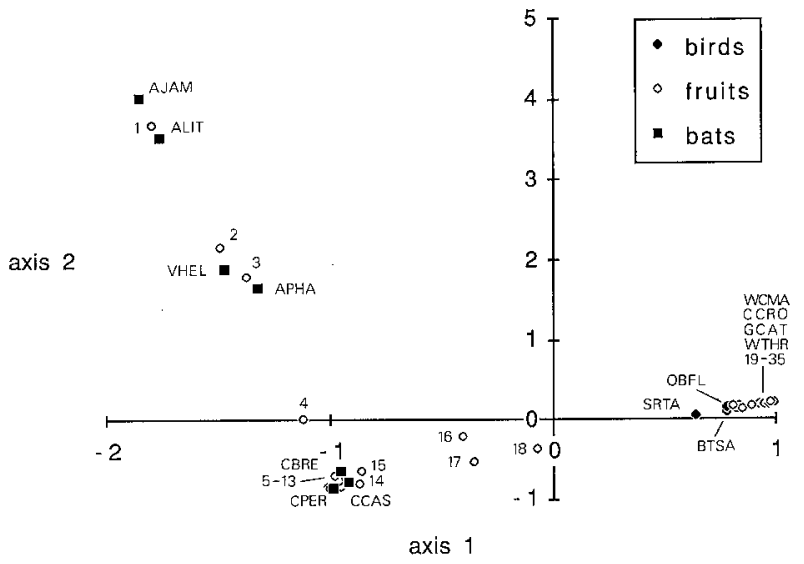

Fig. 1. Plot of the first two axes from Reciprocal Averaging of the diet matrix (Table 1). See Table 1 for identification of bird and bat species (four-letter abbreviations) and plant species (numbers)

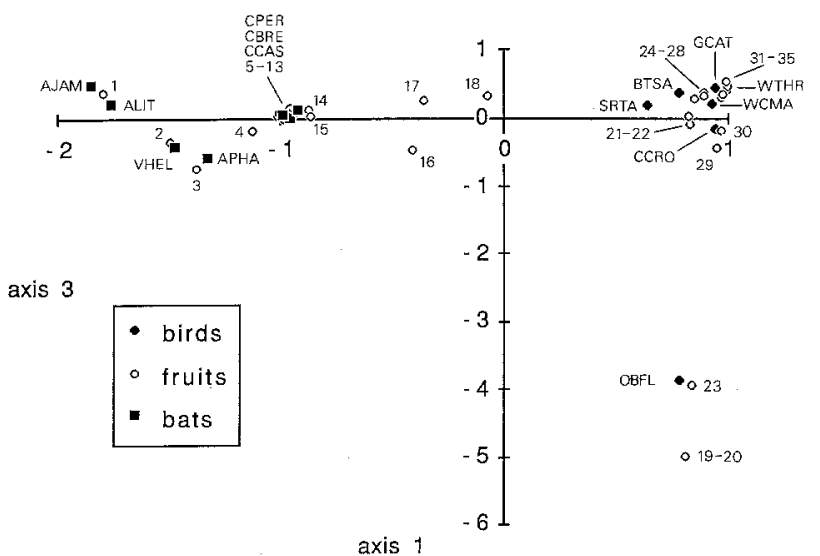

Fig. 2. Plot of the first and third axes from Reciprocal Averaging of the diet matrix (Table 1)
(>6 $\mathrm{mm}$ in length), as is Hampea appendiculata, the other major fruit in its diet (Table 1). Both Casearia and Hampea have arils on their seeds, suggesting that the Ochre-bellied Flycatcher is specialized on fruits with large arillate seeds, while the other six species feed primarily on small-seeded berries such as Hamelia patens and Phytolacca rivinoides.

Niche breadth for bat species tended to be more narrow than for bird species when calculated at the level of plant species (for bats $=3.6$, for birds $x=4.5,0.1>P>0.05$, Table 2). When niche breadth was calculated at the level of plant genus, all bat species had niche breadths smaller than for all 7 bird species (1.0-2.9 vs. 3.2-6.0).

Dietary overlaps between frugivore species are given in Table 3. Overlaps between bird species were all fairly high (0.12-0.88), although the Ochre-bellied Flycatcher had moderately low overlap with each of the other species ( $0.12-0.25$ vs. $0.20-0.88$ for other pairs of bird species). Overlaps between bat species ranged from 0 to 0.89 but had a low mean (0.18). Results of the simulation study show that average overlap between bird species was statistically higher than average overlap between bat species $(P<$ 0.01 ). Overlap between bird-bat species pairs was zero (40 species pairs) or small ( 9 species pairs: range $=0.01-0.08$ ) The greatest overlap between bird and bat species was between the Scarlet-rumped Tanager and each of the three Carollia spp. $(0.05-0.08)$. While these overlaps are much less than those between this Tanager and other bird species $(0.21-0.85)$ or between Carollia spp. $(0.49-0.60)$, they are larger than the overlaps between Carollia and non-Carollia bat pairs $(0-0.04)$. These dietary overlaps should be interpreted with caution since they may not be independent of sample size.

Seeds of Piper friedrichsthalli from fecal samples of Scarlet-rumped Tanager and two Carollia bat species germinated to the same high percentage as seeds from ripe fruits (Table 4; G tests n.s.). Germination percentage of $P$. sancti- 
Table 1 (continued)

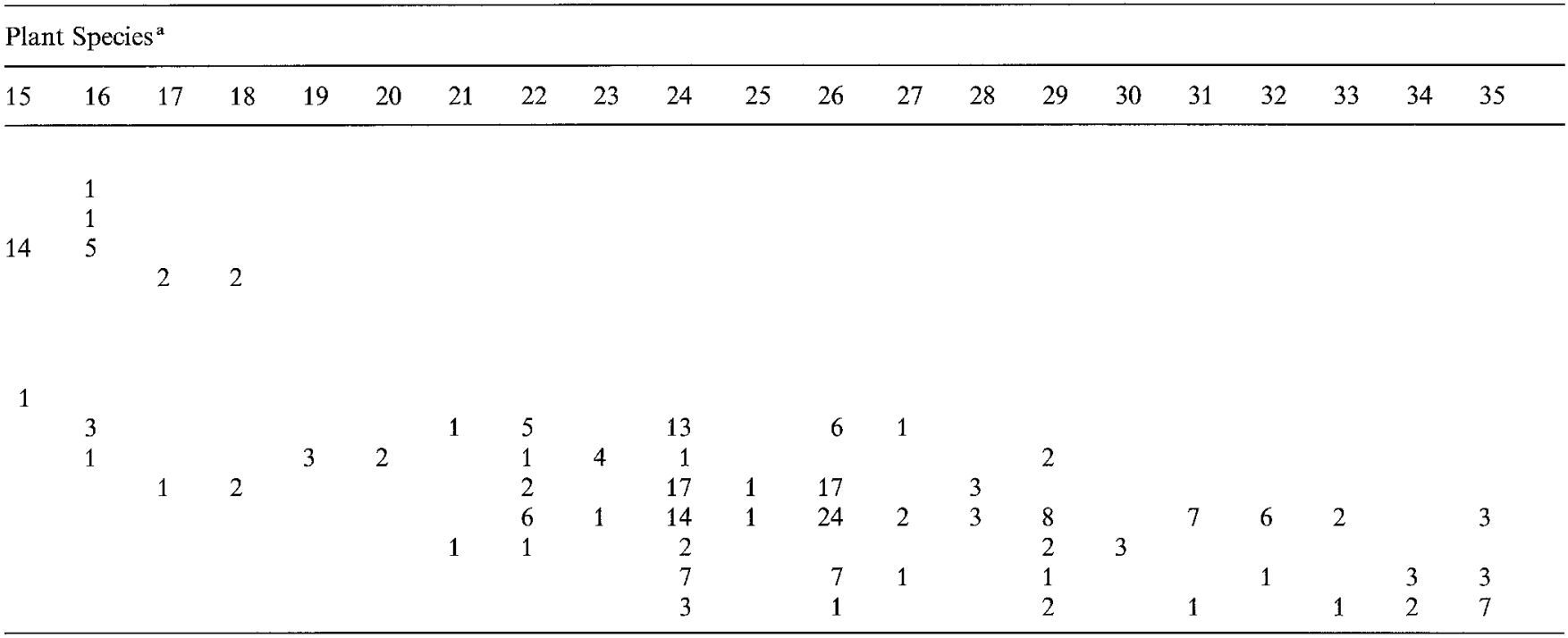

Table 2. Records of intact seeds and arthropod parts from birds and bats captured in the successional strips and niche breadths based on diet samples with seeds. Niche breadths were calculated separately using plant species and plant genus (see Methods)

\begin{tabular}{|c|c|c|c|c|c|c|}
\hline \multirow[t]{2}{*}{ Species } & \multirow{2}{*}{$\begin{array}{l}\text { Animals } \\
\text { Captured }\end{array}$} & \multirow{2}{*}{$\begin{array}{l}\text { Total Diet } \\
\text { Samples }\end{array}$} & \multicolumn{2}{|c|}{ Diet Samples with: } & \multirow[b]{2}{*}{ Species } & \multirow{2}{*}{$\begin{array}{l}\begin{array}{l}\text { Niche } \\
\text { breadth }\end{array} \\
\text { Genus }\end{array}$} \\
\hline & & & Seeds & Arthropods & & \\
\hline Artibeus jamaicensis & 10 & 5 & 5 & 0 & 1.0 & 1.0 \\
\hline Artibeus lituratus & 16 & 10 & 10 & 0 & 1.7 & 1.7 \\
\hline Vampyrops helleri & 8 & 5 & 5 & 0 & 1.5 & 1.5 \\
\hline Carollia brevicauda & 77 & 67 & 59 & 0 & 8.8 & 2.8 \\
\hline Carollia castanea & 55 & 52 & 51 & 0 & 5.4 & 1.3 \\
\hline Other bat species & 58 & 35 & 5 & 22 & - & - \\
\hline Total bats & 276 & 211 & 169 & 24 & - & - \\
\hline Ramphocelus passerinii Scarlet-rumped Tanager & 22 & 19 & 17 & 9 & 4.0 & 4.0 \\
\hline Mionectes oleagineus Ochre-bellied Flycatcher & 36 & 23 & 15 & 10 & 5.5 & 5.5 \\
\hline Hummingbirds & 145 & 0 & - & - & - & - \\
\hline Other bird species & 216 & 144 & 27 & 78 & - & - \\
\hline Total birds & 585 & 333 & 168 & 164 & - & - \\
\hline
\end{tabular}

felicis seeds from Scarlet-rumped Tanager feces was similarly high.

\section{Exclosure experiments}

On the $P$. friedrichsthalli treelets exposed only to bats (treatment 1) $100 \%$ and $96 \%$ (pooled: $97 \%$ ) of the fruits that ripened during the nine day census period were removed (Table 5). Treelets exposed only to birds (treatment 2) had $86 \%, 77 \%$, and $43 \%$ (pooled: $56 \%$ of ripe fruits removed. The number of $P$. friedrichsthalli fruits taken during the day versus during the night on control plants varied greatly $(22: 1,2: 13,4: 4)$; overall $61 \%$ were taken during the day and $39 \%$ at night. The proportion of ripe fruit taken by bats was much higher ( $97 \%$ vs. $39 \%)$ when birds were excluded.

Diameter at last measurement did not differ between $P$. friedrichsthalli fruits taken during the day $(x=4.5 \mathrm{~mm} \pm$ $0.3(\mathrm{SD}) N=12)$ and night $(x=4.4 \mathrm{~mm} \pm 0.4(\mathrm{SD}) \mathrm{N}=5$ ) (Student's $t=0.9 P>0.1$ ). Since fruits swell during ripening, this result suggests that birds and bats took fruits of similar maturity. Ripe fruits were rarely found except on an additional plant protected day and night. We could not deter- 
Table 3. Fruit diet overlap between pairs of frugivore species. ${ }^{a}$ See Table 1 for key to species abbreviations

\begin{tabular}{|c|c|c|c|c|c|c|c|c|c|c|c|c|c|}
\hline & ALIT & VHEL & APHA & CPER & CBRE & CCAS & SRTA & OBFL & BISA & WCMA & CCRO & GCAT & WTHR \\
\hline AJAM & 0.89 & 0 & 0 & 0 & 0.03 & 0 & 0 & 0 & 0 & 0 & 0 & 0 & 0 \\
\hline ALIT & & 0.38 & 0.29 & 0 & 0.03 & 0.02 & 0 & 0 & 0 & 0 & 0 & 0 & 0 \\
\hline APHA & & & & 0.01 & 0.04 & 0.04 & 0.04 & 0.03 & 0 & 0 & 0 & 0 & 0 \\
\hline CPER & & & & & 0.49 & 0.50 & 0.05 & 0.01 & 0 & 0 & 0 & 0 & 0 \\
\hline CBRE & & & & & & 0.60 & 0.08 & 0.03 & 0.02 & 0 & 0 & 0 & 0 \\
\hline OBFL & & & & & & & & & 0.12 & 0.20 & 0.25 & 0.13 & 0.13 \\
\hline BTSA & & & & & & & & & & 0.82 & 0.34 & 0.88 & 0.33 \\
\hline WCMA & & & & & & & & & & & 0.35 & 0.82 & 0.42 \\
\hline $\mathrm{CCRO}$ & & & & & & & & & & & & 0.20 & 0.27 \\
\hline GCAT & & & & & & & & & & & & & 0.63 \\
\hline
\end{tabular}

a Index of overlap is C, Horn's (1966) modification of Morisita's index of overlap

Table 4. Germination of Piper seeds from ripe fruit and fecal samples of Scarlet-rumped Tanager, Carollia brevicauda, and C. perspicillata. Percent germination of $P$. friedrichsthalli seeds from each the three animal species did not differ from the pooled control treatments $(P>0.05$, two-way $G$-tests)

\begin{tabular}{lllll}
\hline Seeds & Source & $\begin{array}{l}\text { No. } \\
\text { Germi- } \\
\text { nated }\end{array}$ & $\begin{array}{l}\text { No. } \\
\text { failed to } \\
\text { Germi } \\
\text { nate }\end{array}$ & $\begin{array}{l}\text { Percent } \\
\text { Germi- } \\
\text { nation }\end{array}$ \\
\hline P. friedrichsthalli & C. brevicauda & 48 & 7 & $87 \%$ \\
$P$. friedrichsthalli & C. perspicillata & 46 & 3 & $94 \%$ \\
$P$. friedrichsthalli & Tanager & 17 & 3 & $85 \%$ \\
$P$. friedrichsthalli & Ripe fruit & 59 & 6 & $91 \%$ \\
$P$. friedrichsthalli & Ripe fruit & 52 & 6 & $90 \%$ \\
$P$. sancti-felicis & Tanager & 9 & 1 & $90 \%$ \\
\hline
\end{tabular}

mine whether fruit ripening tended to occur at a particular time of day.

\section{Discussion}

There is some dietary overlap between frugivorous birds and bats in early successional vegetation at La Selva. The two taxa do tend to eat different fruits and are separated on the first axis by Reciprocal Averaging. The greatest dietary overlap between bird and bat species is between the Scarlet-rumped Tanager and the three species of Carollia bats. These bats primarily feed on Piper spp., which was a minor component of the diet of this tanager. Although this overlap was not large, it was larger than the overlap between the Carollia bats and the four other frugivorous bats, which fed primarily on Ficus and Cecropia. Dietary overlap was also found between the Buff-throated Saltator and C. castanea on Lycianthes and between this saltator and C. brevicauda on no 15 . This bird species overlapped with Carollia spp. on Solanum rugosum during the mid dry season of 1982 (Gorchov and Palmeirim 1982), but only bats fed on this species in the present study, perhaps because ripe $S$. rugosum fruits were much less abundant than in the 1982 study. Additional dietary overlap occurred at the genus level: Clay-colored Robins and Artibeus bats overlapped on Ficus, but they ate different Ficus species.

Many studies have found that phyllostomid bats eat Piper fruits and disperse their seeds (see Fleming 1985 for summary), but our search of the literature revealed only a few studies reporting birds eating Piper (Table 6). Most records are for tanagers (subfamily Thraupinae), as in this study. Why might tanagers and not other frugivorous birds eat Piper? Perhaps tanagers are better able to grip these relatively large fruits in their bill and strip off pulp (tanagers are "mashers" whereas most frugivorous birds are "gulpers", Levey 1987).

While few studies have investigated dietary overlap between unrelated species active at different times of day, earlier studies of related species found that some sets of species used the same habitat and food resources but were active at different times, although this was more common among carnivores than among other trophic groups (Schoener 1974). Counter to earlier assumptions, pairs of related carnivore species active at the same time of day do not have consistently higher dietary overlaps than do

Table 5. Removal of marked fruit from Piper friedrichsthalli treelets exposed to bats (covered during the day), exposed to birds (covered at night), or exposed to both (controls: not covered). Fruits were scored as fallen if they were recovered intact on screen below the treelet and as eaten if they were found stripped of pulp on the screen or on the plant, or if they were not recovered

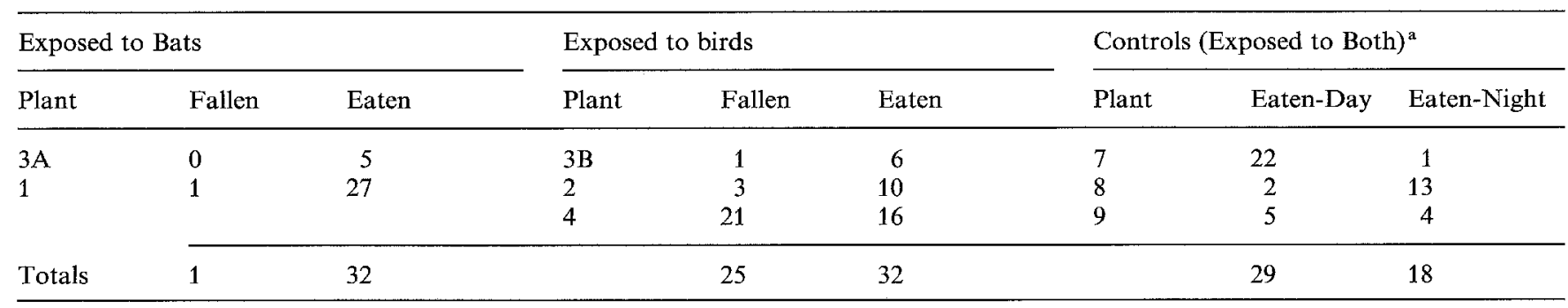


Table 6. Records of birds eating fruits of Piper species and other Piperaceae

\begin{tabular}{|c|c|c|}
\hline Family and Species & $\begin{array}{l}\text { Piper species } \\
\text { eaten }\end{array}$ & $\begin{array}{l}\text { Refer- } \\
\text { ence }^{a}\end{array}$ \\
\hline \multicolumn{3}{|l|}{ Emberizidae: Thraupinae } \\
\hline Dacnis cayana & Pothomorphe & 4 \\
\hline Euphonia violacea & $P$. sp. & 6 \\
\hline E. fulvicrissa & $\begin{array}{l}P . \text { leptocladum } \\
\text { P. marginatum } \\
\text { Pothomorphe }\end{array}$ & $\begin{array}{l}4 \\
4 \\
4\end{array}$ \\
\hline Ramphocelus carbo & $P$. sp. & 2 \\
\hline Tangara inornata & $\begin{array}{l}\text { P. leptocladum } \\
\text { Pothomorphe }\end{array}$ & $\begin{array}{l}4 \\
4\end{array}$ \\
\hline Thraupis episcopus & $\begin{array}{l}P . \text { auritum } \\
P . \text { marginatum } \\
P . \text { sp. }\end{array}$ & $\begin{array}{l}8 \\
4 \\
6\end{array}$ \\
\hline Th. palmarum & P. marginatum & 4 \\
\hline $\begin{array}{l}\text { Pipridae Chiroxiphia linearis } \\
\text { Manacus vitellinus }\end{array}$ & $\begin{array}{l}P . \text { sp. } \\
P . \text { leptocladum? }\end{array}$ & $\begin{array}{l}8 \\
5\end{array}$ \\
\hline Ramphastidae Aulacorhynchus prasinus & P. auritum & 8 \\
\hline Columbidae Ptilinopus pulchellus & "Piperaceae" & 3 \\
\hline Cuculidae Eudynamys & $P$. sp. & 1 \\
\hline Casuariidae Casuarius casuarius & $P$. sp. & 7 \\
\hline
\end{tabular}

a 1. Crome (1978); 2. Foresta et al. (1984), Charles-Dominique and Cooper (1986); 3. Frith et al. (1976); 4. Leck (1971); 5. Leck (1972); 6. Snow and Snow (1971); 7. Stocker and Irvine (1983); 8. Wheelwright et al. (1984)

diurnal-nocturnal species pairs (Jaksić 1982; Huey and Pianka 1983).

\section{Do birds and bats compete for Piper?}

The results of the day vs. night exclosures on Piper friedrichsthalli suggest that tanagers and Carollia compete for Piper fruit, but that this competition is not symmetric. Exposure of $P$. friedrichsthalli plants to birds greatly reduces the proportion of ripe fruits removed by bats $(97 \%$ to $39 \%)$. However, birds take a similar proportion of ripening $P$. friedrichsthalli fruits regardless of whether bats have access to these plants $(56 \%)$ or not $(61 \%)$. These results are consistent with a model of $P$. friedrichsthalli fruit ripening at dawn or during the day, and being reduced, but not depleted, by avian frugivory. Bats then find and eat all remaining fruits during the night. An alternative explanation is that birds regard $P$. friedrichsthalli fruits ripe at an earlier stage than bats, but this is unlikely, due to the size similarity between diurnally and nocturnally removed fruits. For whatever reason, ripe $P$. friedrichsthalli fruit appears to be a resource that bats deplete daily but birds do not. Whether this holds for the other Piper species cannot be determined from our data. However, tanagers and Carollia spp. do overlap on several Piper species, and it is possible that frugivory by tanagers has a significant impact on this major food of these bats. On the other hand, even if bat frugivory did significantly reduce the availability of Piper fruits to tanagers, we suggest that this would have less effect on the tanagers since Piper comprises a smaller portion of their diet.
The ratio of diurnally vs. nocturnally removed fruits varied greatly among control $P$. friedrichsthalli treelets. Similarly, the proportion of ripe fruits removed from treelets exposed only to birds was very variable. These results suggest that some treelets are visited primarily by birds and other primarily by bats. The reason for such differential use of conspecific fruit trees is not known at this time, but might involve differences in fruit quality or the proximity of treelets to 1) bat flyways (Palmeirim and Etheridge 1985), 2) larger trees that provide night roosts or feeding perches for bats or cover from predators for birds, or 3) the center of feeding ranges of individual tanagers.

Both the Scarlet-rumped Tanager and Carollia bats defecate germinable Piper seeds and hence are seed dispersal agents. However, the bats probably provide higher quality dispersal since tanagers often strip Piper fruits, removing part of the fruit but leaving the rest on the plant. These stripped fruits generally fall below the plant, precluding dispersal of the remaining seeds by volant frugivores.

\section{Trophic structure of the frugivore community}

Bat species tended to have more specialized diets than bird species, which tended to exploit more evenly the "bird fruits". Large overlap on fruit species among frugivorous bird species has been noted by other authors (Terborgh and Diamond 1970; Snow and Snow 1971; Lack 1976; Frith et al. 1976) although Crome $(1975,1978)$ found overlaps to be relatively low. All seven of the major frugivorous bird species in this study also ate arthropods, as do most frugivorous birds (McKey 1975) so the total dietary overlaps may differ from the overlaps on fruit.

The two bird species with the most similar diets were the two North temperate migrants, Gray Catbird and Wood Thrush. Their similar values for the first three RA axes is largely attributable to their shared use of a few fruit species present in the successional strips but not taken by other frugivores (Table 1 ).

In our study bats tended to be more specialized than birds and were more divergent in their diets, based on the lower average overlap between species pairs and the fact that bat species accounted for most of the variance after the first RA axis, which separated birds and bird-fruits from bats and bat-fruits). A more throughout study of frugivorous bats (Bonaccorso 1979) also found that they grouped into distinct guilds.

The major frugivorous bats in our study fell into two clusters, the three Carollia species, which fed primarily on Piper spp., and the three Artibeus species plus Vampyrops helleri, which fed largely on Ficus spp. and Cecropia obtusifolia (Figs. 1, 2). These groups are congruent with two of the nine feeding guilds recognized by Bonaccorso (1979) on Barro Colorado Island, Panama. His groundstory frugivore guild consisted of two of the three Carollia species in our study. Other studies of Carollia spp. in Costa Rica have also found that Piper spp. predominate in the diet, comprising $45-57 \%$ of samples (Fleming 1986). At La Selva all three Carollia species ate a variety of Piper species, consistent with Fleming's (1985) finding that co-occuring Piper species in Guanacaste have very similar sets of bat seeddispersal agents.

The other four major frugivorous bats in our study were included, along with three other species, in the "canopy 
frugivore guild" by Bonaccorso (1979). He noted that all but one of these species (A. phaeotis) were specialized on Ficus spp. We also found that Ficus comprised a smaller proportion of the diet of $A$. phaeotis than it did of the diets of the larger A. jamaicensis and A. lituratus. The importance of Ficus spp. in the diets of these larger Artibeus spp. has also been reported for three sites in Costa Rica (Fleming 1986) and in Veracruz, Mexico (Vazquez-Yanes et al. 1975; Estrada et al. 1984b).

\section{How common is dietary overlap between birds and bats?}

Is dietary overlap between birds and bats confined to particular seasons? Diets of frugivores are known to change over the course of the year as the availability of different fruit species changes (e.g. Leck 1972; Crome 1975; Heithaus et al. 1975; Vazquez-Yanes et al. 1975; Bonaccorso 1979). Dietary overlap between frugivore species can therefore also change dramatically from month to month, as Crome (1975) demonstrated for fruit pigeon species in northern Queensland. Studies that average data over many months or the entire year (e.g. the reanalysis of Bonaccorso's (1979) data by Humphrey et al. (1983)) will not detect periods of high overlap.

Crome (1975) found peaks of dietary overlap during months of both minimum and maximum fruit abundance. Our study was done during the early dry season, a time when fruit abundance is low and ripe fruit removal rates are high at this site (Denslow and Moermond 1982). For this reason we expected overlap between birds and bats to be at a maximum at this time, although the opposite is predicted if the period of food abundance is marked by a few patchy or highly profitable resources (Schoener 1982). However, a preliminary study done in the mid dry season of 1982 found somewhat greater overlap between birds and bats than this study (Gorchov and Palmeirim 1982).

Is the dietary overlap between birds and bats found in this study typical of tropical systems? In early successional vegetation in Guyana diurnal frugivory, attributed to birds, has been reported for several fruits eaten primarily by bats: Loreya mespiloides ( $43 \%$ of fruits removed during the day), Cecropia obtusa (17\%), Piper sp. $(6 \%)$, Solanum rugosum $(6 \%)$, and Vismia guianensis $(3 \%)$ (Charles-Dominique and Cooper 1986). These percentages may be underestimates since the authors note that some fruits eaten by birds may have been scored as removed at night. It is possible that overlap is greater in early successional sites than in mature forest where plants and dispersers may be more specialized. Additional local studies are needed to test this hypothesis. Even if overlap is largely limited to early successional vegetation, it may have important ecological consequences since successional vegetation is covering an increasing proportion of the tropical landscape due to deforestation.

Other investigators have found dietary overlap between frugivorous neotropical birds and bats. August (1981) documented the importance of the bat $A$. jamaicensis to seed dispersal of Ficus trigonata in the llanos of Venezuela, and referred to a list of birds eating these fruits at the same site compiled by Morton (1979). Estrada et al. (1984a) found that 33 bird species, two bat species, 11 other mammal species, one reptile, and one insect eat fruits of Cecropia obtusifolia in Veracruz, Mexico. Fleming et al. (1985) found that six bird species, six bat species, four terrestrial mam- mals, and several insect species eat fruits of Muntingia calabura in dry forest in Costa Rica. Taken together, these studies suggest that dietary overlap between frugivorous birds and bats may be a common phenomenon. However, the number of fruit species shared by birds and bats may be small. Only 13 of 169 fruit species eaten by birds in a Costa Rican cloud forest were also eaten by bats (Fleming 1986, based on data of Wheelwright et al. 1984 and Dinerstein 1983). Fleming et al. (1987) argue that dietary overlap between frugivorous birds and bats is somewhat greater in the Old World tropics than in the neotropics, based on the greater number of fruit genera known to be eaten by both taxa.

Studies that do not investigate the possibility of frugivory during both day and night may produce an incomplete description of a system. For example, Stemmadenia donnellsmithii has been reported to be dispersed by birds and monkeys by McDiarmid et al. (1977) and Cant (1979), but we found bats of the genus Micronycteris feeding regularly on these fruits at La Selva.

This study shows that birds reduce the availability of a fruit resource important to bats, at least at one location during one season. Along with recent studies of utilization of particular fruit species by both birds and bats cited above, this result questions the earlier conclusion that competition between these taxa is negligible (Fleming 1979). This conclusion had been based on comparisons of diet lists compiled separately for birds and bats by different investigators at different sites and at different times, because simultaneous local comparisons were not available. Further local community level studies of frugivory by both birds and bats are needed to determine the seasonal and geographic extent of dietary overlap and competition for fruit between birds and bats. Despite the presumed coevolution of plants with dispersal agents in a particular taxon, competition for fruit may not be limited to species in the same taxon and competitive interactions between distantly related species need to be considered.

Acknowledgements. We are grateful to Solveig Thorsteinsdottir for her assistance with the field work. O. Rocha, O. Vargas, D.A. Clark, J. Denslow, and R. Lopez helped with plant and seed identification, as did D. Levey's La Selva seed collection. D. Kearns generously shared his field sites and knowledge of their birds. G. Estabrook kindly did the simulation. K. Warwick provided the CORAN program for Reciprocal Averaging. Earlier drafts of this manuscript were improved by the comments of D. Levey, T. Fleming, and B. Rathcke. The faculty of the 1982 Organization for Tropical Studies (OTS) course (B. Williamson, S. Bennett, K. Grove, and E. Stashko) supported our initial interest in this study. We are grateful to D.B. and D.A. Clark, O. Rocha, and the OTS staff at the La Selva Biological Station in San Jose for their assistance. This project was funded by a Jessie Smith Noyes Fund grant (administered by OTS) to JP and DLG and a Rackham Block Grant from the University of Michigan to DLG.

\section{References}

August PV (1981) Fig fruit consumption and seed dispersal by Artibeus jamaicensis in the llanos of Venezuela. Biotropica 13 (Suppl): 70-76

Bonaccorso FJ (1979) Foraging and reproductive ecology in a Panamanian bat community. Bull Fl State Mus Biol Sci 24:359 408

Bonaccorso FJ, Glanz WE, Sandford CM (1980) Feeding assemblages of mammals at fruiting Dipteryx panamensis (Papilionaceae) trees in Panama; seed predation, dispersal and parasitism. Rev Biol Trop 28:61-72 
Brown JH, Davidson DW, Reichman OJ (1979) An experimental study of competition between seed eating rodents and ants. Am Zool 19:1129-1144

Cant JGH (1979) Dispersal of Stemmadenia donnell-smithii by birds and monkeys. Biotropica $11: 122$

Charles-Dominique P, Cooper HM (1986) Frugivorie et transport des graines de Cecropia par les chauves-souris en Guyane. Mem Mus Natl Hist Nat Ser A: Paris 132:145-157

Crome FHJ (1975) The ecology of fruit pigeons in tropical Northern Queensland. Aust Wildl Res 2:155-185

Crome FHJ (1978) Foraging ecology of an assemblage of birds in lowland rainforest in northern Queensland. Aust J Ecol $3: 195-212$

Denslow JS, Moermond TC (1982) The effect of accessibility on rates of fruit removal from tropical shrubs: an experimental study. Oecologia (Berlin) 54:170-176

Dinerstein E (1983) Reproductive ecology of fruit bats and the seasonality of fruit production in a Costa Rican cloud forest. $\mathrm{Ph}$. D. dissertation, University of Washington, Seattle

Estrada A, Coates-Estrada R, Vazquez-Yanes C (1984a) Observations on fruiting and dispersers of Cecropia obtusifolia at Los Tuxtlas, Mexico. Biotropica 16:315-318

Estrada A, Coates-Estrada R, Vazquez-Yanes C, Orozco-Segovia A (1984b) Comparison of frugivory by howling monkeys (Alouatta palliata) and bats (Artibeus jamaicensis) in the tropical rain forest of Los Tuxtlas, Mexico. Am J Primatol 7:3-13

Fleming TH (1979) Do tropical frugivores compete for food? Am Zool 19:1157-1172

Fleming TH (1985) Coexistence of five sympatric Piper (Piperaceae) species in a tropical dry forest. Ecology 66:688-700

Fleming TH (1986) Opportunism versus specialization: the evolution of feeding strategies in frugivores and seed dispersal. $\mathrm{Dr}$ W. Junk Publishers, Dordrecht, pp 105-118

Fleming TH, Breitwisch R, Whitesides GH (1987) Patterns of tropical vertebrate frugivore diversity. Annu Rev Ecol Syst 18:91-109

Fleming TH, Williams CF, Bonaccorso FJ, Herbst LH (1985) Phenology, seed dispersal, and colonization in Muntingia calabura, a neotropical pioneer tree. Am J Bot 72:383-391

Foresta H de, Charles-Dominique P, Erard C, Prevost MF (1984) Zoochronie et premiers stades de la regeneration naturelle apres coupe en foret guyanaise. Rev Ecol (Terre Vie) 39:369-400

Frith HJ, Crome FHJ, Wolfe TO (1976) Food of fruit pigeons in New Guinea. Emu 76:49-58

Gauch HG (1982) Multivariate analysis in community ecology. Cambridge University Press, Cambridge

Gautier-Hion A, Duplantier J-M, Quris R, Feer F, Sourd C, Decoux J-P, Dubost G, Emmons L, Erard C, Hecketsweiler P, Moungazi A, Roussilhon C, Thiollay J-M (1985) Fruit characters as a basis of fruit choice and seed dispersal in a tropical forest vertebrate community. Oecologia (Berlin) 65:324337

Gorchov DL, Palmeirim JM (1982) Fruit use by birds and bats in the La Selva successional strips. In: Williamson GB (ed) Organization for Tropical Studies 1982-1 coursebook. Durham, NC, pp 388-393

Hartshorn GS (1983) Plants: introduction. In: Janzen DH (ed) Costa Rican natural history. University of Chicago Press, Chicago, IL, pp 118-157

Heithaus ER, Fleming TH, Opler PA (1975) Foraging Patterns and resource utilization in seven species of bats in a seasonal tropical forest. Ecology 56:841-854

Holdridge LR, Grenke WC, Hatheway WH, Liang T, Tosi JA Jr (1971) Forest environments in a tropical life zones: a pilot study. Pergamon Press, Oxford New York

Horn HS (1966) Measurement of "overlap" in comparative ecological studies. Am Nat 100:419-424

Howe HF (1986) Seed dispersal by fruit-eating birds and mammals. In: Murray DR (ed) Seed dispersal. Academic, New York, pp 123-189

Huey RB, Pianka ER (1983) Temporal separation of activity and interspecific dietary overlap. In: Huey RB, Pianka ER, Schoener TW (eds) Lizard ecology. Harvard University Press, Cambridge, MA, pp 281-290

Humphrey SR, Bonaccorso FJ, Zinn TL (1983) Guild structure of surface-gleaning bats in Panama. Ecology 64:284-294

Jaksić FM (1982) Inadequacy of activity time as a niche difference: the case of diurnal and nocturnal raptors. Oecologia (Berlin) $52: 171-175$

Janson CH (1983) Adaptation of fruit morphology to dispersal agents in a neotropical forest. Science 219:187-189

Johnson RA, Willson MF, Thompson JN, Bertin RI (1985) Nutritional values of wild fruits and consumption by migrant frugivorous birds. Ecology 66:819-827

Knight RS, Siegfried WR (1983) Inter-relationships between type, size, and colour of fruits and dispersal in sourthern African trees. Oecologia (Berlin) 56:405-412

Lack D (1976) Island biology. Blackwell, Oxford

Lebart L, Morineau A, Warwick KM (1984) Multivariate descriptive statistical analysis. John Wiley, New York

Leck CF (1971) Overlap in the diet of some neotropical birds. Living Bird 10:89-106

Leck CF (1972) Seasonal changes in feeding pressures of fruitand nectar-eating birds in Panama. Condor 74:54-60

Levey DJ (1986) Fruit-frugivore interactions in a Costa Rican rainforest. $\mathrm{Ph} . \mathrm{D}$. dissertation, University of Wisconsin, Madison

Levey DJ (1987) Seed size and fruit-handling techniques of avian frugivores. Am Nat 129:471-485

Levins R (1968) Evolution in changing environments: some theoretical explorations. Princeton University Press, Princeton, NJ

McDiarmid RM, Ricklefs RE, Foster MS (1977) Dispersal of Stemmadenia donnell-smithii (Apocynaceae) by birds. Biotropica 9:9-25

McKey D (1975) The ecology of coevolved seed dispersal systems. In: Gilbert LE, Raven PH (eds) Coevolution of animals and plants. University of Texas Press, Austin, pp 159-191

Morton ES (1979) A comparative survey of avian social systems in northern Venezuelan habitats. In: Eisenberg JF (ed) Vertebrate ecology in the northern Neotropics. Smithsonian Institution Press, Washington, DC, pp 233-259

Palmeirim JM, Etheridge K (1985) The influence of man-made trails on foraging by tropical frugivorous bats. Biotropica $17: 82-83$

Pielou EC (1984) The interpretation of ecological data. John Wiley, New York

Pijl L van der (1957) The dispersal of plants by bats (chiropterochory). Acta Bot Neerl 6:291-315

Pijl L van der (1982) Principles of dispersal in higher plants. 3rd. ed. Springer, Berlin Heidelberg New York

Schoener TW (1974) Resource partitioning in ecological communities. Science 185:27-39

Schoener TW (1982) The controversy over interspecific competition. Am Sci 70:586-595

Snow BK, Snow DW (1971) The feeding ecology of tanagers and honeycreepers in Trinidad. Auk 88:291-322

Snow DW (1971) Evolutionary aspects of fruit-eating by birds. Ibis 113:194-202

Sokal RR, Rohlf FJ (1969) Biometry. Freeman and Company, San Francisco

Stocker GC, Irvine AK (1983) Seed dispersal by Cassowaries ( $\mathrm{Ca}$ suarius casuarius) in North Queensland rainforests. Biotropica $15: 170-176$

Terborgh JW, Diamond JM (1970) Niche overlap in feeding assemblages of New Guinea birds. Wilson Bull 82:29-52

Vazquez-Yanes C, Orozco A, Francois G, Trejo L (1975) Observations on seed dispersal by bats in a tropical humid region in Veracruz, Mexico. Biotropica 7:73-76

Wheelwright NT, Haber WA, Murray KG, Guindon C (1984) Tropical fruit-eating birds and their food-plants: a survey of a Costa Rican lower montane forest. Biotropica 16:173-192

Received July 7, 1987 